Brit. J. industr. Med., 1964, 21, 218.

\title{
PREVALENCE OF PNEUMOCONIOSIS IN CORNISH KAOLIN WORKERS
}

\author{
BY \\ GEOFFREY SHEERS \\ From the Plymouth and District Hospital Group \\ (RECEIVED FOR PUBLICATION NOVEMBER 29, 1963)
}

\begin{abstract}
In 1961, 553 Cornish china clay workers had been exposed to kaolin dust for periods exceeding five years, and evidence of kaolinosis was seen in $48(9 \%)$. No kaolinosis was found in men who had been exposed for less than five years. Workers in the more heavily exposed jobs of milling, bagging, and loading showed a prevalence rising from $6 \%$ in those with between five and 15 years' exposure to $23 \%$ in those exposed for more than 15 years. Men who had been intermittently and less heavily exposed in the older, out-dated drying plants needed 25 years' exposure before reaching the highest prevalence of $17 \%$.

Massive fibrosis has been observed in two cases in the industry and also in two men who have left the industry. Six men needed anti-tuberculous chemotherapy, but none had a positive sputum. Preventive measures now include pre-employment chest examination, but the problems of dust control have not yet been satisfactorily solved.
\end{abstract}

In 1956, Hale, Gough, King, and Nagelschmidt published details of six cases of pneumoconiosis in Cornish kaolin workers. Post-mortem histological studies and chemical analysis were carried out in one case and additional histological and chemical evidence was obtained from the post-mortem examination of an American kaolin worker; in both cases the disease was complicated, in the first by frank tuberculosis and in the second by massive fibrosis. The lesions were found to differ from those of classical silicosis and showed certain resemblances to coal-miners' pneumoconiosis. In the three uncomplicated cases the radiographs showed diffuse, fine, nodular mottling.

Edenfield (1960) has examined 1,130 kaolin workers in Georgia. The dust exposure of these men is not given, but the kaolin was finely divided and contained no free silica. Bagging and loading were the main causes of dust. Forty-four (3.7\%) cases of pneumoconiosis were found, and in this group 42 had been exposed for more than 10 years and 19 for more than 20 years. In 31 cases the radiographs showed simple micronodular pneumoconiosis; seven showed confluent shadows probably corresponding to category $\mathrm{A}$, and six showed massive fibrosis.

A further six cases with comparable radiographic appearances have recently been reported by Warraki and Herant (1963) in a survey of Egyptian clay workers handling unrefined clay consisting mainly of potassium aluminium silicate, with a free silica content similar to that of Cornish kaolin.

In animal experiments (King, Harrison, and Nagelschmidt, 1948) the reaction to kaolin has been mainly a reticulinosis not comparable with the reaction to a fibrogenic dust such as quartz. Other experiments (Attygalle, Harrison, King, and Mohanty, 1954) have demonstrated that a combination of kaolin and dead tubercle bacilli caused a mainly collagenous reaction leading to well-marked fibrosis. Furthermore, this reaction was more pronounced than that caused by a combination of anthracite and dead tubercle bacilli.

The condition is now well recognized, and further studies have revealed over 60 cases in Cornwall. The name 'kaolinosis' (Lynch and McIver, 1954) is a convenient descriptive term and will be used in this paper.

Chest radiography surveys within the industry were not possible in the early years of the National Health Service, and the first public surveys in the neighbourhood of the main Cornish clay area were limited to the larger towns and failed to reveal evidence of pneumoconiosis. In 1955, public surveys were extended to villages in the St. Austell area, and from this date onwards a series of cases of 
kaolinosis emerged. Surveys of dock labourers at Fowey followed, and workers in the Lee Moor area east of Plymouth were examined in 1956. In 1960 it became possible to carry out a survey of all classes of worker in the industry in the St. Austell area; 1,540 men were examined, and 27 cases of pneumoconiosis were identified. As a result of these findings agreement was reached with the principal group of china clay companies for a more detailed study of men working in the clay drying installations to be carried out in 1961. The purpose was to obtain more precise information regarding the prevalance of kaolinosis in the industry and to relate it to the conditions of work and length of exposure. It is with the findings in the 1961 survey that this paper is concerned.

\section{Industrial Processes}

China clay is obtained by washing out the decomposed felspar from the walls of the open pit by means of a high pressure water jet. Impurities, mainly mica and sand, are removed by differential sedimentation, the clay remaining in suspension.

The refined clay is conveyed by pipe line to the drying plant which may be situated at a considerable distance from the pit. The traditional method of drying the clay is carried out in a coal-fired open pan kiln. After running off the supernatant fluid from the settling tanks, the clay, known at this stage as 'muck', and having a jelly-like consistency with a water content of $70 \%$, is shovelled by hand into trucks and then tipped on to the tiled floor or 'pan' of the kiln where it is broken and spread for drying. The settling process has now been superseded in all but a few of the older plants by filter presses which reduce the water content to $30 \%$ by compression between finely woven nylon cloths, the resulting clay having the consistency of putty.

The moisture content is reduced to about $10 \%$ in the kiln, and the clay is then shovelled into linhays where it is stored. This process causes much visible air-floated dust and is carried out daily. In a few plants, the recent introduction of a pugmill for throwing the clay from the pan to the linhay has caused an obvious increase in the amount of dust.

Mechanical shovels are being used to an increasing extent for loading the clay from the linhay into the lorries or railway wagons. This job is very dusty but may not take place more than once a week.

During the last 15 years the drying process has been concentrated into fewer, fully mechanized plants capable of handling much greater quantities of clay. The clay is de-watered by the filter press technique, fragmented in a pug-mill and fed by conveyor belt into a cylindrical drum drier. Heating is by steam pipes, or by oil-fired furnace flue pipes, or, in some recent installations, by the furnace gases in direct contact with the clay.

The clay leaves the drier with a moisture content of a little below $10 \%$. The belts carrying the clay after drying are sometimes partially shielded to collect falling particles, and in the more modern plants there is not much dust apparent in the atmosphere, though it collects quickly in ventilation louvres and on the floor. Floor cleaning can cause much dust, but vacuum methods are now being tried. Cleaning the driers, especially the older steam-heated type, has to be carried out inside the drum and is extremely dusty work.

Certain specialized clays are further processed to achieve the required standards of particle size (between 1 and 2 microns) and moisture content (between $1 \%$ and $4 \%$ ). Clay for this treatment is dropped into a hopper from which it is fed to an attritor mill and drier, heated by an oil-fired furnace. The whole process appears well enclosed. These highly refined products are bagged for loading and distribution.

For bulk loading the clay is simply allowed to fall from the belt to form large dumps in the loading bays. Mechanical shovels are extensively used and cause large dust clouds which may be aggravated by the wind. The introduction of larger pay loaders lifting up to $30 \mathrm{cwt}$. seems likely to increase the problem (Fig. 1).

For bagging, hand shovels have been replaced by machines, but the process remains dusty, and a cloud of finely divided clay is blown into the face of the bagger at the moment when the bag is filled.

Occupational Structure.-In the old-fashioned kiln driers the whole of the process was carried out by the same team of men, known as kilnworkers. These men handled dry clay for roughly a third of their working time, but this proportion has increased substantially as a result of the introduction of filter pressing which is a specialized job carried out by pressmen.

Many kilnworkers have transferred to the modern drying plants, where men working in the processing section of the building include pressmen, pugmill operators, firemen, fitters, cleaners, and maintenance men. Cleaners and maintenance men may be exposed from time to time to concentrations of dust above the average level and have been grouped under the heading of 'drymen' in the occupational classification.

In the loading section of the building, men handling the more highly refined clay describe themselves as millers, baggers, and loaders. There are no clear divisions between these jobs, and all the men are 


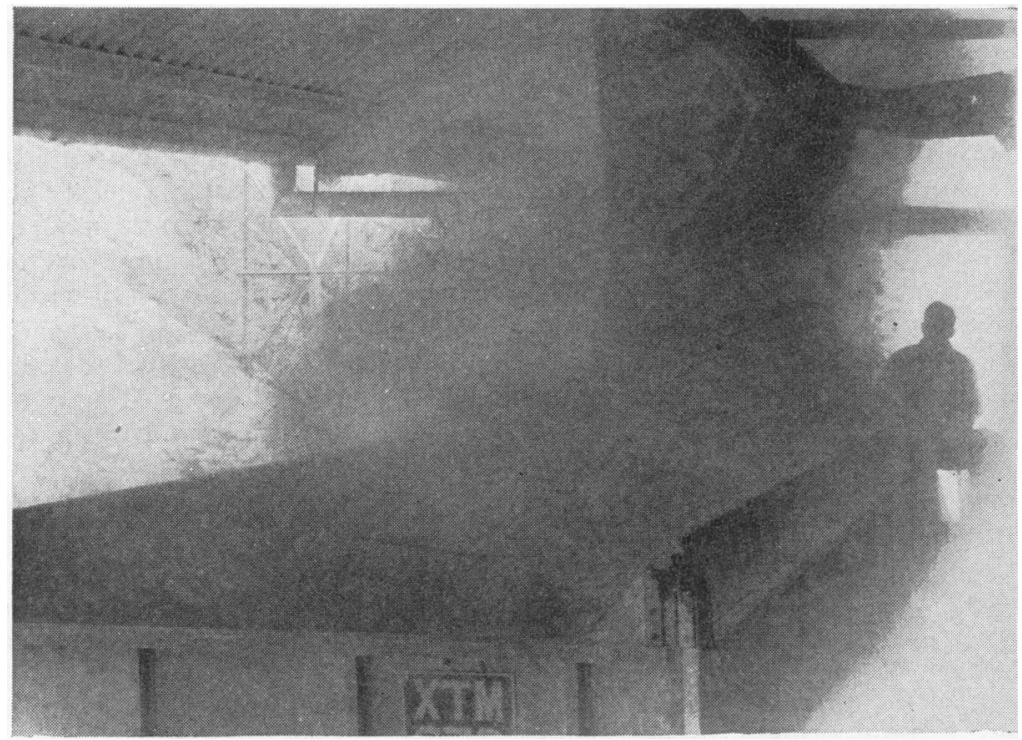

Fig. 1.-Bulk loading of kaolin into lorry.

exposed to the dust caused by the bagging process. In addition, millers may be required from time to time to clean out the hoppers and are then exposed to greater concentrations of dust.

Bulk loading is a specialized job carried out by pay-loader drivers. Some of them wear goggles, an observation which gives some impression of the density of the air-borne dust. Lorry drivers may assist in the loading and unloading of their lorries but are not exposed to dust for more than a small portion of their working time.

The neighbouring china stone quarries and mills are now incorporated within the organization of the clay industry, and the jobs involved are referred to under the headings of stone millers, crushers, packermen, and quarrymen.

\section{Methods and Material}

The 1961 Survey.-The china clay industry is largely under the control of one firm which produces over three quarters of the total product. Two mechanized drying plants under the management of independent companies were omitted from the survey. All the men examined were thus under a single management, and uniform conditions of admission to the survey could be applied. All employees having any connexion with the drying plants were included. Chest radiography was made a condition of employment in this section of the industry at the same time, and in this way a full response was ensured. Defaulters during the main survey were examined at a return visit. The pro- cessing section constitutes roughly one third of the labour force of the industry, the other sections being concerned with pit work, transport, engineering, and by-products.

Following a pilot survey in the processing plant near Plymouth, the main survey was carried out at five centres in the St. Austell area and also at two outlying centres on Bodmin moor and near Liskeard.

The number of men examined was 1,394. Their occupations at the time of the survey are recorded in Table 1. The occupations above the dotted line

TABLE 1

MEN EXAMINED IN 1961, BY OCCUPATION

\begin{tabular}{l|c}
\hline \multicolumn{1}{c|}{ Occupation } & No. \\
\hline Millers, baggers, and loaders & 246 \\
Kilnworkers and drymen & 355 \\
\hline---------171 \\
Pressmen & 134 \\
Firemen & 80 \\
Stonemillers, crushers, packermen, and quarrymen & 408 \\
\hline Others & 1,394 \\
\hline
\end{tabular}

are those carrying a risk of exposure to clay dust and total 601. Under the heading of 'others' are included managers, clerks, storemen, and others whose work only occasionally took them inside the buildings of the drying plant.

Industrial History Analysis.-Industrial histories were recorded for all the men examined and were carefully checked by an experienced clerk who was well versed in the oddities of local terms and usages. 
In all cases where a radiographic abnormality was suspected the history was rechecked by the writer.

The frequency of changes of occupation coupled with the variability of the dust hazard in many of the jobs caused much difficulty in the assessment of exposure, but it became clear that the dusty occupations could be allocated to one of two classes, $\mathrm{A}$ and $\mathrm{B}$, as follows:

Class A: Those in which the work is consistent in character throughout the working shift and where the exposure is more or less continuous. Millers, baggers, and loaders come under this heading.

Class B: Those in which the work varies from time to time during the shift and where the exposure to dust is intermittent. Kilnworkers and drymen are included under this heading.

In the analysis, the results of which are set out in Table 2, men whose industrial history included five

TABLE 2

INDUSTRIAL HISTORY GROUPING

\begin{tabular}{l|l|c}
\hline \multicolumn{1}{c|}{ Group } & \multicolumn{1}{c|}{ Definition } & No. \\
\hline I Class A & $\begin{array}{l}\text { Men with over five years' exposure as } \\
\text { millers, baggers, and loaders } \\
\text { Men with over five years' exposure as } \\
\text { kilnworkers and drymen }\end{array}$ & 255 \\
Class B & $\begin{array}{l}\text { Men with less than five years' exposure } \\
\text { Men with negligible exposure } \\
\text { Men with exposure to other dust for } \\
\text { more than five years }\end{array}$ & 553 \\
\hline II ---111 \\
III
\end{tabular}

years or more in one or other or both of these classes were placed in group $I$, and this group was subdivided into class $\mathbf{A}$ and class B. Men who had worked in both classes of jobs but who had spent the greater part of the time as millers, baggers, or loaders were included in class A. Group II consists of men whose total exposure to dust amounts to less than five years. Men in group III have had negligible dust exposure. Group IV includes men with more than five years' exposure to other forms of dust, mainly china stone.

No case of kaolinosis has been seen in men with an exposure of less than five years, and the studies of prevalence have therefore been related to the 553 men constituting group I.

Radiographic Classification.-The technique of radiography conformed to the standards agreed at the Meeting of Experts at Geneva in 1958, and the international classification established at the same meeting (I.L.O., 1959) was used in the categorization of abnormalities.

All films were read by two observers, and cases in which either observer has expressed doubt as to the presence of an abnormality (including those in categories $L$ and $Z$ ) have been excluded from the series of cases of kaolinosis.

The abnormal films were categorized by direct comparison with a set of standard films reproduced by the International Labour Office.

\section{Results}

Prevalence of Kaolinosis.-Forty-eight cases of kaolinosis were found in the 553 men exposed (group I). The prevalence was found to rise from $4 \%$ in those with an exposure of less than 15 years to $19 \%$ in those with an exposure of more than 25 years. There was also a progressive rise in prevalence with age from none below the age of 25 to $24 \%$ over the age of 65 years. The full analysis is given in Table 3.

Classes A and B were analysed separately and compared in order to evaluate the effect of changes in the occupational structure of the industry (Table 4).

The prevalence in class A was $13 \%$ compared with $5 \%$ in class B. The higher prevalence in class A was seen throughout the age and exposure range. An additional 10 years of age was needed in class B to reach a level of prevalence similar to that in class A. In the analysis by length of exposure, a sudden rise in the prevalence rate was noted in both classes, but whereas this occurred after 15 years' exposure in

TABLE 3

KAOLINOSIS RELATED TO AGE AND EXPOSURE IN GROUP I

\begin{tabular}{|c|c|c|c|c|c|c|c|c|c|c|}
\hline \multirow{3}{*}{$\begin{array}{l}\text { Age } \\
\text { (years) }\end{array}$} & \multicolumn{10}{|c|}{ Exposure (years) } \\
\hline & \multicolumn{2}{|c|}{$5-14$} & \multicolumn{2}{|c|}{$15-24$} & \multicolumn{2}{|c|}{$25-34$} & \multicolumn{2}{|c|}{$35+$} & \multicolumn{2}{|c|}{ Total } \\
\hline & $\begin{array}{c}\text { No. } \\
\text { Examined }\end{array}$ & $\begin{array}{c}\text { Cases of } \\
\text { Kaolinosis }\end{array}$ & $\begin{array}{c}\text { No. } \\
\text { Examined }\end{array}$ & $\begin{array}{c}\text { Cases of } \\
\text { Kaolinosis }\end{array}$ & $\begin{array}{c}\text { No. } \\
\text { Examined }\end{array}$ & $\begin{array}{c}\text { Cases of } \\
\text { Kaolinosis }\end{array}$ & $\begin{array}{c}\text { No. } \\
\text { Examined }\end{array}$ & $\begin{array}{c}\text { Cases of } \\
\text { Kaolinosis }\end{array}$ & $\begin{array}{c}\text { No. } \\
\text { Examined }\end{array}$ & $\begin{array}{c}\text { Cases of } \\
\text { Kaolinosis }\end{array}$ \\
\hline $\begin{array}{l}15-24 \\
25-34 \\
35-44 \\
45-54 \\
55-64 \\
65+\end{array}$ & $\begin{array}{r}11 \\
86 \\
99 \\
78 \\
36 \\
4\end{array}$ & $\begin{array}{l}- \\
4 \\
5 \\
4 \\
1\end{array}$ & $\begin{array}{r}-10 \\
37 \\
48 \\
34 \\
7\end{array}$ & $\begin{array}{l}-1 \\
3 \\
6 \\
4 \\
-\end{array}$ & $\begin{array}{r}- \\
3 \\
33 \\
29 \\
4\end{array}$ & $\begin{array}{l}- \\
5 \\
7 \\
2\end{array}$ & $\begin{array}{l}\overline{-} \\
\overline{5} \\
19 \\
10\end{array}$ & $\begin{array}{c}- \\
\overline{-} \\
3 \\
3\end{array}$ & $\begin{array}{r}11 \\
96 \\
139 \\
164 \\
118 \\
25\end{array}$ & $\begin{array}{r}-1 \\
7 \\
16 \\
18 \\
6\end{array}$ \\
\hline Total & 314 & 14 & 136 & 14 & 69 & 14 & 34 & 6 & 553 & 48 \\
\hline
\end{tabular}


TABLE 4

KAOLINOSIS RELATED TO AGE AND EXPOSURE

\begin{tabular}{|c|c|c|c|c|c|c|c|c|c|c|}
\hline \multirow{3}{*}{$\begin{array}{l}\text { Age } \\
\text { (years) }\end{array}$} & \multicolumn{10}{|c|}{ Exposure (years) } \\
\hline & \multicolumn{2}{|c|}{$5-14$} & \multicolumn{2}{|c|}{$15-24$} & \multicolumn{2}{|c|}{$25-34$} & \multicolumn{2}{|c|}{$35+$} & \multicolumn{2}{|c|}{ Total } \\
\hline & $\begin{array}{c}\text { No. } \\
\text { Examined }\end{array}$ & $\begin{array}{c}\text { Cases of } \\
\text { Kaolinosis }\end{array}$ & $\begin{array}{c}\text { No. } \\
\text { Examined }\end{array}$ & $\begin{array}{c}\text { Cases of } \\
\text { Kaolinosis }\end{array}$ & $\begin{array}{c}\text { No. } \\
\text { Examined }\end{array}$ & $\begin{array}{c}\text { Cases of } \\
\text { Kaolinosis }\end{array}$ & $\begin{array}{c}\text { No. } \\
\text { Examined }\end{array}$ & $\begin{array}{c}\text { Cases of } \\
\text { Kaolinosis }\end{array}$ & $\begin{array}{c}\text { No. } \\
\text { Examined }\end{array}$ & $\begin{array}{c}\text { Cases of } \\
\text { Kaolinosis }\end{array}$ \\
\hline $\begin{array}{c}\text { Class } A \text {. } \\
15-24 \\
25-34 \\
35-44 \\
45-54 \\
55-64 \\
65+\end{array}$ & 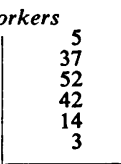 & $\begin{array}{c}\text { 二 } \\
4 \\
2 \\
2 \\
1\end{array}$ & $\begin{array}{r}7 \\
16 \\
17 \\
10 \\
3\end{array}$ & $\begin{array}{r}-1 \\
3 \\
6 \\
2 \\
\end{array}$ & $\begin{array}{r}- \\
1 \\
17 \\
18 \\
3\end{array}$ & $\begin{array}{l}\text { 二 } \\
\overline{3} \\
4 \\
2\end{array}$ & $\begin{array}{l}\overline{-} \\
\overline{9} \\
1\end{array}$ & $\bar{E} \frac{-}{1}$ & $\begin{array}{r}5 \\
44 \\
69 \\
76 \\
51 \\
10\end{array}$ & $\begin{array}{r}-1 \\
7 \\
11 \\
9 \\
4\end{array}$ \\
\hline Total & 153 & 9 & 53 & 12 & 39 & 9 & 10 & 2 & 255 & 32 \\
\hline $\begin{array}{c}\text { Class } B \text { W } \\
15-24 \\
25-34 \\
35-44 \\
45-54 \\
55-64 \\
65+\end{array}$ & \begin{tabular}{|r} 
orkers \\
6 \\
49 \\
47 \\
36 \\
22 \\
1
\end{tabular} & $\begin{array}{l}- \\
\overline{3} \\
2 \\
\end{array}$ & $\begin{array}{r}-3 \\
21 \\
31 \\
24 \\
4\end{array}$ & $\begin{array}{c}\bar{Z} \\
\frac{2}{2}\end{array}$ & $\begin{array}{r}- \\
2 \\
16 \\
11 \\
1\end{array}$ & $\begin{array}{c}- \\
\overline{2} \\
\frac{3}{-}\end{array}$ & $\begin{array}{r}- \\
5 \\
10 \\
9\end{array}$ & $\overline{-}$ & $\begin{array}{r}6 \\
52 \\
70 \\
88 \\
67 \\
15\end{array}$ & $\begin{array}{c}\text { 二 } \\
\overline{5} \\
9 \\
2\end{array}$ \\
\hline Total & 161 & 5 & 83 & 2 & 30 & 5 & 24 & 4 & 298 & 16 \\
\hline
\end{tabular}

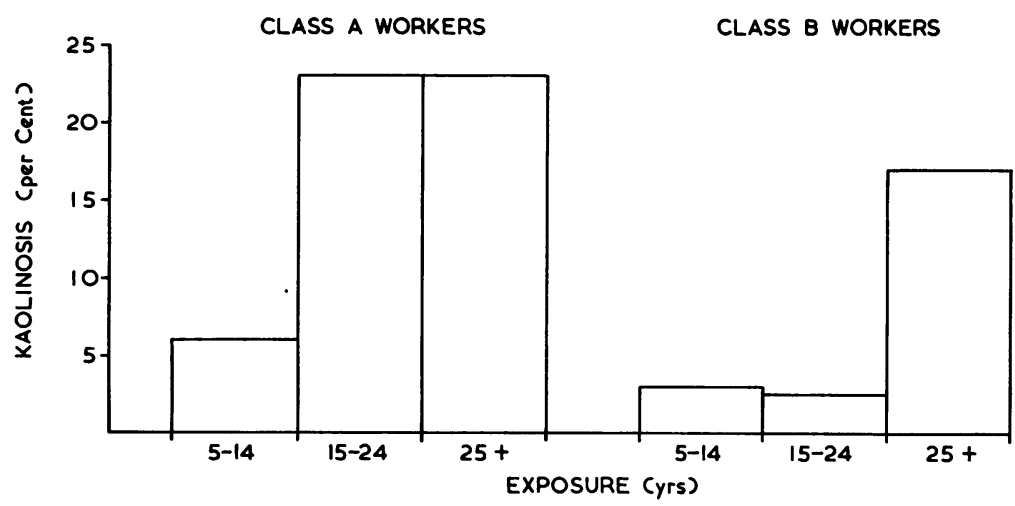

Fig. 2.-Prevalence of kaolinosis related to exposure.

class A, it required over 25 years' exposure in class B and then reached only $17 \%$ as compared with $23 \%$ in class A. These differences are illustrated in Figure 2.

The number of cases of kaolinosis was too small for a comparison to be made in each subdivision of age and exposure, but certain statistically significant differences were noted. In the age group 35-44, there was a significant difference between class A (seven cases in 69) and class B (no cases in 70). In the age group 45-54, those with an exposure of more than 15 years showed a significant difference between class A (nine cases in 34) and class B (two cases in 52). In the same age group there was a significant difference within class $\mathrm{A}$ between those exposed less than 15 years (two cases in 42) and those exposed more than 15 years (nine cases in 34).

Radiographic Categories in Kaolinosis.-The radiographic categories of the 48 cases of kaolinosis 


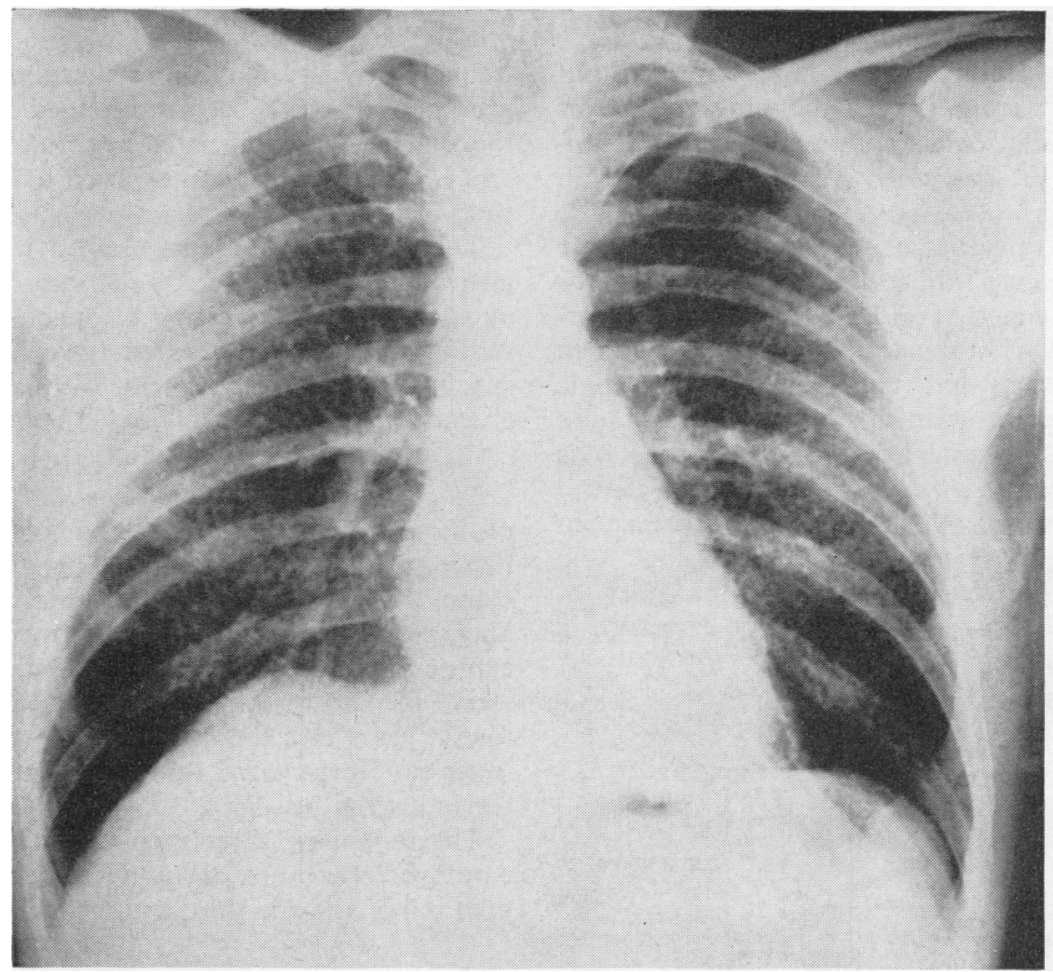

FIG. 3.-A.E.G., aged 53, after 16 years' bagging and milling. Kaolinosis, category $3 \mathrm{~m}$.

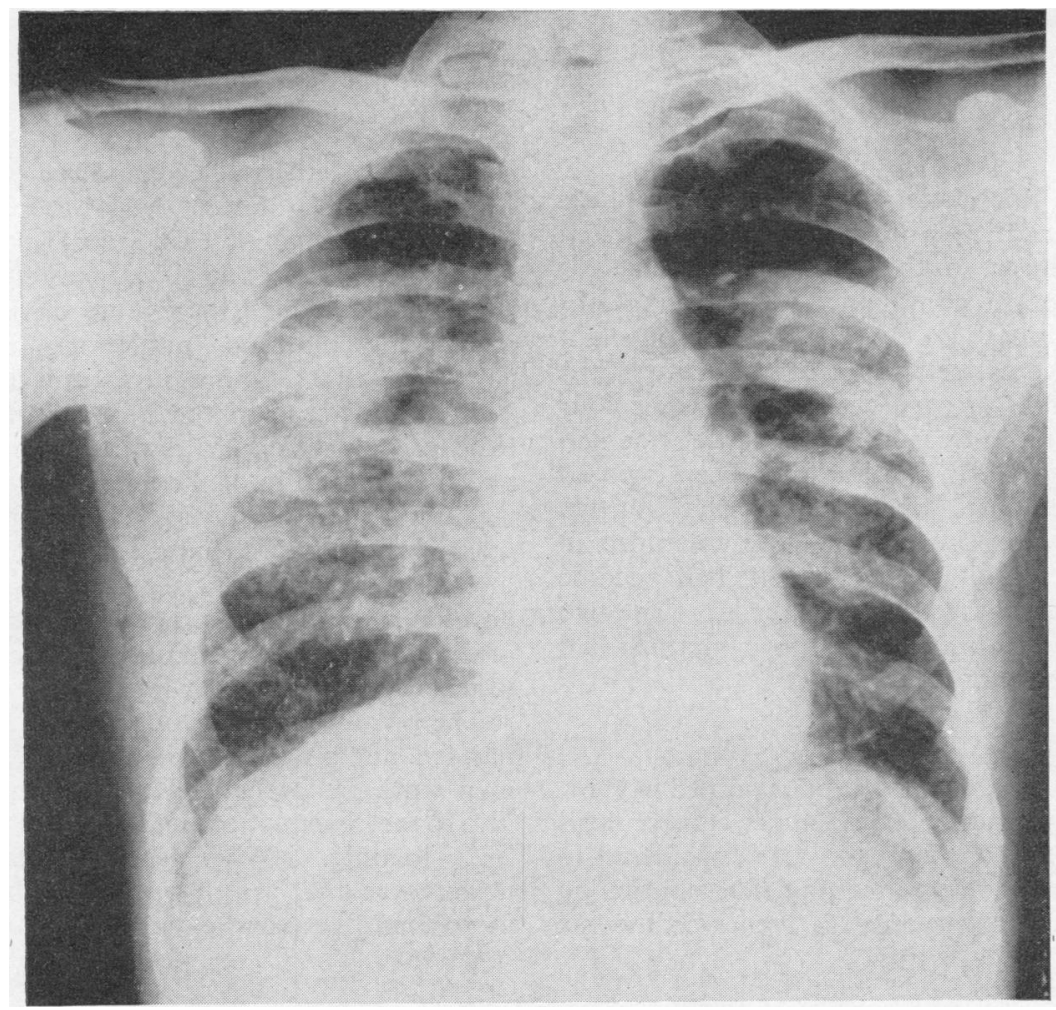

FIG. 4.-S.C., aged 62, after 32 years' bagging. Kaolinosis, category 3B. 
more than usually difficult, and as all suspected but doubtful cases were rejected, the number in this category is small. An example of a typical uncomplicated case (category $3 \mathrm{~m}$ ) is illustrated in Figure 3.

Of the larger opacities, those in category $\mathrm{A}$ have shown little change whilst under observation for periods of between two and eight years. A tuberculous aetiology is suspected in two cases, and in one of these there has been some radiographic progression, but no organisms have yet been found in the sputum. In one other case the opacity is denser than average and contains a small central zone of calcification. A similar centre is present in one of the category B opacities (Fig. 4).

The relation between radiographic category of simple pneumoconiosis and length of exposure is illustrated in Figure 5.

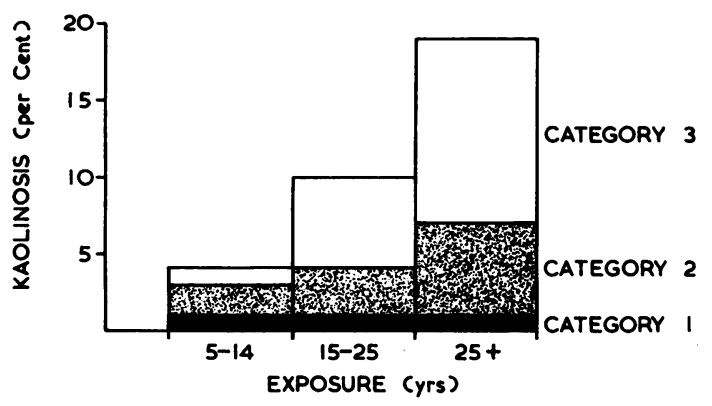

Fig. 5.-Radiographic category related to exposure.

Disability in Kaolinosis.-There was very little evidence of disability which could be attributed solely to kaolinosis in the 48 cases seen in this survey. Thirteen men complained of mild symptoms of shortness of breath on exertion, or showed slight distress after an exercise tolerance test. In four, the disability was due to cardiovascular disease; four were overweight and over 55 years of age; one had pulmonary tuberculosis and had also been exposed to china stone dust; one had massive fibrosis (category B) with a normal exercise tolerance in 1955 , but by 1961 , at the age of 59 , had become disabled and had changed to a lighter job. The two remaining men with mild subjective symptoms had no clinical evidence of disability.

\section{Other Diseases}

Tuberculosis.-In the 1,394 men examined in 1961, radiographic evidence of pulmonary tuberculosis was found in 15. Of these, six were considered to need chemotherapy, the remaining nine continuing under occasional observation. None of the six treated men had a positive sputum, and only one was kept off work for a prolonged period. In one the disease was associated with simple kaolinosis, and two others had been exposed to kaolin for more than five years.

The 12 men with complicated kaolinosis (categories $\mathbf{A}$ and $\mathbf{B})$ have been re-examined at intervals, and one with category $A$ opacities has shown radiographic changes which have been sufficiently specific to justify treatment with anti-tuberculous chemotherapy.

Silicosis.-There were 14 cases of silicosis. Nine of these were in men who had spent periods of between five and 28 years milling or packing china stone. All but one of these nine men had been diagnosed previously; three of them had also been exposed to kaolin. Two other cases of silicosis were found in men working in china stone quarries, one for 28 years and the other for 38 years, but in the latter case three years' tin mining must be added to the industrial history.

The remaining three men with silicosis had been employed elsewhere, one in a wolfram mine, one in a gold mine, and the third as a granite mason.

Carcinoma.-One case of carcinoma of the bronchus was found in the survey, but the exposure to kaolin was insignificant.

\section{Discussion}

Factors Affecting the Prevalence of Kaolinosis.Many factors interfere with the assessment of exposure to dust in this industry, but it seemed justifiable to assess the risk separately for groups of jobs between which there were obvious differences in working conditions, and to compare the results. This was all the more important in view of the post-war increase in the number of more heavily exposed jobs which has resulted from the expansion and mechanization of the industry.

This comparison shows clearly that men who have worked as millers, baggers, and loaders at any stage in their career stand a significantly greater risk of developing kaolinosis, and that it is likely to develop after a shorter exposure and at an earlier age than in men working in other jobs.

The increase in the production of clay since 1945 has led not only to an increase in the number of men working in the pre-existing class $\mathrm{A}$ jobs, but also to the introduction of the specialist in mechanical bulk loading. When the group of pay-loader drivers was analysed, it was found that only 12 had more than five years' exposure, and none had more 
than 15 years' exposure. No kaolinosis was found in this very small group, but if the conditions of work remain the same, it appears very probable that cases will be found when more men have been exposed for longer periods.

Dockers provide a comparable group, especially 'bottom-men' working in a ship's hold and handling clay delivered by chute. Four cases of kaolinosis were found among 30 dockers examined at Fowey in 1955 , and a fifth case was diagnosed at a later examination. The minimum exposure necessary to produce kaolinosis under these conditions cannot be deduced from this small group, since all but two of the $\mathbf{3 0}$ dockers already had a lengthy exposure at the time of their first examination.

The significance of occasional exposure to very high concentrations of dust can be seen in a small group of men working in a section of the industry not included in the survey. Here the drum driers require internal cleaning by maintenance men at approximately three-weekly intervals, and attention from fitters at irregular and less frequent intervals. During this short exposure the men are necessarily in a confined space. Three cases of kaolinosis have been seen in men employed in this way.

Complications and Disability.-The slight disabling effects of kaolinosis seen in men still at work in the industry should not be allowed to obscure the potential dangers of the condition. Massive fibrosis has been observed in four out of a total of 67 known cases in Cornwall and has led to serious degrees of disability.

A much higher proportion of complicated cases has been reported in the survey of Egyptian clay workers (Warraki and Herant, 1963), and it is evident that the prevalence of pulmonary tuberculosis is relevant to this problem. In the Egyptian survey there were 14 cases of active tuberculosis among the 914 men examined. The risk of pneumoconiosis in this environment appeared small (less than $1.5 \%$ in men with an exposure of over 15 years) but there were three complicated cases among the six cases of pneumoconiosis, one with active tuberculosis, one with category A opacities, and one with massive fibrosis.

In the American survey (Edenfield, 1960) no case of active pulmonary tuberculosis was found. The notification rate for the white population was 36 per 100,000 compared with 109 per 100,000 for the negro population. It was considered significant that five of the six cases of massive fibrosis were in negroes.

In Cornwall it is fortunate that the industry is situated in an area where the prevalence of tubercu- losis is relatively low. The average notification rate of respiratory tuberculosis during the decade 195160 in the St. Austell rural district, where most of the workers live, was 50 per 100,000 . In the parts of Cornwall to the west of St. Austell the rate for the same period was 79 .

The number of men given anti-tuberculous chemotherapy as a result of the survey appears high, but allowance must be made for its use as a preventive rather than a therapeutic measure in many cases. The essential feature was that no evidence was found of infectious disease.

It is too early to assess with any certainty the risk of progressive tuberculosis in those cases with category A radiographs, but it appears unlikely that tuberculosis will present the problem in this industry that it does in association with silicosis in the neighbouring granite industry. The introduction of pre-employment chest radiography coupled with regular resurveys should do much to reduce the risk to a minimum.

Dust Control.-To the outside observer the main sources of dust appear to arise in the bagging process and in the use of crude methods of bulk storing and loading. Dust extraction devices near the nozzles of some of the bagging machines are being tried but do not appear very effective.

Vacuum cleaning methods and better enclosure of conveyor belts are other improvements which need to be applied more extensively. It will be difficult to overcome the problems of dust in bulk handling unless some reorganization of the loading process can be undertaken. Storage hoppers with enclosed delivery chutes feeding the clay by gravity to the wagons would be a possible method but would necessarily involve considerable expenditure on reconstruction of the buildings.

I owe much to Dr. L. W. Hale for his constant encouragement and advice, and also to Dr. Ann Templeton for help in film reading, and to Dr. R. N. Curnow, Unit of Biometry, University of Reading, for statistical advice. This work would not have been possible without the loyal support of the staff of the Mass Radiography Service.

\section{REFERENCES}

Attygalle, D., Harrison, C. V., King, E. J., and Mohanty, G. P. (1954). Brit. J. industr. Med., 11, 245.

Edenfield, R. W. (1960). Arch. environm. Hlth, 1, 392.

Hale, L. W., Gough, J., King, E. J., and Nagelschmidt, G. (1956) Brit. J. industr. Med., $13,251$.

International Labour Office (1959). Occup. Safety Hlth 9, 63.

King, E. J., Harrison, C. V, and Nagelschmidt, G. (1948), J. Path. Bact., 60, 435 .

Lynch, K. M., and McIver, F. A. (1954). Amer. J. Path., 30, 1117.

Warraki, S., and Herant, Y. (1963). Brit. J. industr. Med., 20, 226. 